\title{
KUYPERANIA IN 2015
}

\section{Author:}

S. Bishop ${ }^{1}$

\section{Affiliation:}

${ }^{1}$ City of Bristol College, Bristol

\section{Correspondence to:}

Steve Bishop

\section{Postal Address:}

100 North Rd, Stoke Gifford, Bristol BS34 8PE, England

Email:

stevebishop.uk@gmail.com

Dates:

15 Dec. 2016

\section{How to cite this article:} Bishop, S., 2016. "Kuyperania in 2015". KOERS - Bulletin for Christian Scholarship, 81(3). Available at: https://doi. org/10.19108/KOERS.81.3.2230

\section{Copyright:}

(c) 2016. The Author(s). Published under the Creative Commons Attribution License.
This article looks at new works published in 2015 on or about Abraham Kuyper.

KEY CONCEPTS: Abraham Kuyper, Common grace, Sphere sovereignty

$\ldots \ldots \ldots \ldots \ldots \ldots \ldots \ldots \ldots \ldots \ldots$

Hierdie artikel kyk na nuwe werk gepubliseer in 2015 op of oor Abraham Kuyper

KERNBEGRIPPE: Abraham Kuyper, Algemene genade, Sfeersoewereiniteit

\section{INTRODUCTION}

2015 was a good year for works on or by Abraham Kuyper, illustrating once again the resurgence of interesting all things Kuyper. Two books were written developing a different perspective on him - one by Glenn Friesen (2015) which emphasized the influence of Van Baader on Kuyper and the other by Mark Larson (2015) who wants to co-opt Kuyper as a political conservative. There were two main works of translation produced - one from the Lexham Press which now seems to be the preferred publisher of the Kuyper Translation Project - the other is published by Friesen Press (no connection, as far as I am aware, to Glenn Friesen). There were also several papers published developing some aspect or another of Kuyper's thought. And of course, there is the usual publication of the Kuyper Centre Review now in its fifth year.

In what follows I shall examine these publications and mention some reviews of Kuyper works from previous years.

\section{BY KUYPER}

The Kuyper Translation Project has been working to translate and publish a number of works by Kuyper. Several of these had been published by Christian's Library Press - the publishing arm of the Acton Institute (Kuyper 2011, 2013a, b, c, 2014). Now the Lexham Press ${ }^{1}$ has announced the publication of several newly-translated volumes by Kuyper, under the title: Abraham Kuyper Collected Works in Public Theology. They will include the three volumes of Common Grace, three volumes of Pro Rege, Our Program and a series of anthologies:

- On Charity and Justice - which includes a new translation of The Problem of Poverty

- On Islam - pieces gathered from his reflections on a lengthy tour of the Mediterranean world ${ }^{2}$

- On the Church - with selections from Kuyper's doctrinal dissertation on the theologies of Reformation theologians John Calvin and John a Lasco, 'Rooted and Grounded', 'Twofold Fatherland' and 'Address on Missions'.

1 Lexham Press is part of Faithlife, who also produced the popular Logos Bible Software. Kuyper's Collected Works will also be published electronically on the Logos platform.

2 The documentary based on Kuyper's book Om de oude wereldzee (Around the Old World Sea) is now available online with English subtitles here: https://vimeo.com/album/3715377 
- On Business and Economics - with various meditations on the evils of the love of money and pieces that provide Kuyper's thoughts on stewardship, human trafficking, free trade, tariffs, child labour, work on the Sabbath and business.

- On Education - this will include the essay 'Bound to the Word.'

These volumes will appear over the next few years. They have also launched a new website: https://abrahamkuyper.com. So far only Our Program: A Christian Political Manifesto has been published (Kuyper 2015), with another Common Grace promised in early 2016.

Full details are - in the style of Kuipers (2011):

\section{5}

\section{Translations}

Our Program: A Christian Political Manifesto

Bellingham, WA: Lexham Press, 2015. xviii + 410pp., $18 \times 25.7 \times 3.6 \mathrm{~cm}-\$ 49.99$ (£42.84)

Run: unknown, Published: 20 November 2015.

Translation of: Ons program 1880.05; republication of Guidance for Christian engagement in government 2013.

Translator: Harry Van Dyke

Introduction by General editors (Jordan J. Ballor and Melvin Flikkema, dated August 2015) and translator and editor (Harry Van Dyke, dated Spring 2013)

Binding: Hardback, ISBN: 978-1577996552

God's Angels: His Ministering Spirits, translated by Richard Stienstra was originally published in Dutch as De Engelen Gods in $1902.07^{3}$ and then republished in a second edition in 1923.06 by J.H. Kok. Here we have Kuyper the theologian. These chapters were originally published in De Heraut over the period June 1894 to November 1895. The latter articles he wrote while convalescing in the French Pyrenees. The 36 articles cover all aspects of angelogy including their existence, their nature their ministry and fallen angels.

Harry Van Dyke has translated Kuyper's “The natural knowledge of God'. This is a translation of Het heil in ons (1879; repr. Kampen: Kok, 1910), pp. 165-225. This study appeared in thirteen instalments in the Sunday supplement of De Standaard, from Aug. 2 to Nov. 15, 1874. It is available online at www. allofliferedeemed.co.uk/kuyper.htm

The numbers by the dates of Kuyper's writings are the designations used in Tjitze Kuiper (2011).
Another short piece by Kuyper has been translated by James A. De Jong: "The Worship of the Reformed Church and the Creation of Its Service Book' (Kuyper, 2015d). This early piece from Kuyper originally published in 1869 looks at, as the title suggests, the creation of the service book by Petrus Datheneus, as he does so he places the worship of the Reformed church in its context and looks at John a Lasco and the resources published after the 1574 Synod of Dordt.

We now turn to two books which present different sides of Kuyper.

\section{ON KUYPER}

\subsection{Conservatism and the Church and State}

Mark Larson (PhD Calvin Seminary) begins his Abraham Kuyper, Conservatism, and the Church and State (Larson, 2015) by acknowledging Kuyper's debt to Calvin, but sees that there is a 'sharp contrast between Calvin and Kuyper on the issues of religious liberty and church disestablishment' (xi). For Larson, Kuyper is a conservative who 'looked to the American constitutional arrangement for his thinking' (xi). There can be no denying that Kuyper was enamoured with the United States - as shown in the letters Kuyper wrote to his family during his 1898 four-month Stone Lectures visit (Kuyper, 2012). However, the claim made by Larson is somewhat exaggerated.

Larson writes out of a North American context where politics seems to be polarised between Democrats (liberals) and Republicans (conservatives). Kuyper wasn't liberal therefore he was perforce a conservative and this almost seems to be the stance taken. "The point that must be remembered is that Kuyper was not a leftist, a liberal, or a progressive in his political views' (9). For Larson conservatism is marked by three traits: the emphasis on God and the moral order; the necessity of limited government; and the commitment to the value of freedom. Kuyper, according to Larson, agreed with these three traits, therefore Kuyper was a Conservative. Kuyper did advocate limited government, but it was not from any conservative impulse, it was derived from his notion of sphere sovereignty. It is sphere sovereignty that gives a specific and limited role to the state, but not only the state, the church, family, business and so on all also have limited roles. The state does have an important role to play in Kuyper's view - the state's role is to intervene in relations between institutions and people to ensure that the interactions between them are just. This is not a position derived from conservatism.

Larson doesn't draw upon Kuyper's Ons Program (see above). If he did then it would become clear that Kuyper was neither left nor right in his politics, neither Democrat nor Republican, neither liberal nor conservative. Kuyper endeavoured to be Christian in his politics.

\subsection{Neo-Calvinism and Christian Theosophy}

Larson attempts to shape Kuyper in the image of conservatism, Friesen (2015) maintains that it is Franz von Baader who has shaped and influenced Kuyper. This is a theme that Friesen 
has developed over a number of years (see for example Friesen, 2003). He has now utilised that work and expanded on it in his new book. Although the book primarily focuses on Dooyeweerd, Kuyper is also discussed. ${ }^{4}$

\section{Dooyeweerd wrote:}

'It has been said so many times that repeating it almost becomes boring: The Philosophy of the Cosmonomic Idea does not pretend infallibility either in respect of its positive philosophical conceptions or with regard to its critique on traditional philosophy' (Dooyeweerd 2013).

This has certainly been evidenced in discussions regarding his supra-temporality of the heart. Here Friesen claims that the idea of a supra-temporal heart, among other ideas of Dooyeweerd, originates not in Kuyper, Groen van Prinsterer or even in Jean Calvin but in the work and writings of the Christian theosophist Franz Xavier von Baader (Friesen, 2015:75).

This book is the result of much more research. It is in three parts. The first looks at the reception of Christian theosophy in neo-Calvinism, the second the development of reformational philosophy and the third a detailed comparison of Dooyeweerd's philosophy with Christian theosophy. It should be mentioned that the theosophy of Baader is far removed from the theosophy of Madame Blavatsky. Von Baader was a Catholic and presents a Christian version of theosophy. In the first section Friesen prevents a helpful overview of the theology and philosophy of von Baader, Daniel Chantepie de la Saussaye (1818-1874), J.H. Gunning Jr. (1829-1905), Kuyper, Fredrick van Eeden (1860-1932) and Jan Woltjer (1848-1917).

Friesen contends that Kuyper's ideas of 'religious antithesis, social organisms, sphere sovereignty, the centrality of the heart, and his opposition to the dogma of theoretical thought are all ideas that are first found in Baader' (Friesen, 2015:75).

This book will no doubt promote controversy - that may not be such a bad thing. It is well-researched treatise and a surprisingly a good read. In a review Nijhof writes that 'Friesen too easily turns similarities into historical relationships, too rashly ignoring other possible sources' but that 'Friesen's research is a steppingstone towards further investigation of similarities and differences between neo-Calvinist philosophies and the broader tradition of Christian thought' (Nijhof, 2015:240).

\subsection{Journal articles}

An organisation that has helped promote the work of Kuyper is the Abraham Kuyper Centre for Public Theology based at Princeton Theological Seminary, the place where Kuyper delivered his Stone Lectures in 1898. Each year the Kuyper Centre holds a Kuyper Conference. These lectures are then usually published in the annual Kuyper Centre Review. The 2016 conference is on 'Religion and journalism'. In 2014 the conference was on 'Philosophy, worship and art' and in 2012 on the 'Church and academy', many of the papers delivered at the 2012 conference were subsequently published in The Kuyper Centre Review volume 5 (Graham, 2015). Not all the papers, however, were on or about Kuyper. Those that were include:

- Michael Bräutigam 'A queen without a throne? Harnack, Schlatter, and Kuyper on theology in the university'

- Gijsbert van den Brink 'Evolution as a bone of contention between church and academy'

- Ad de Bruijne 'Not without the church as institute'

- Dylan Pahman F.W.J. Schelling: a philosophical influence on Kuyper's thought'

\section{- Harry Van Dyke 'Kuyper on the teaching of history'}

- Gordon Graham 'Abraham Kuyper and the idea of a Christian scholar'

Henry Van Til once described Kuyper as the 'theologian of common grace' (Van Til, 1972:117). It is no surprise then that several articles published this year look at his notion of common grace (see, for example, Skaff 2015; van Oorschott, 2015; Heslam, 2015), Kuyper's sphere sovereignty and its application to pluralism and politics is also examined in several papers (Kennedy, 2015; Hiemstra, 2015; Rathbone, 2015).

Skaff, a PhD candidate at Princeton Theological Seminary, in many ways is writing in the shadow of Barth. In his 'Common grace and the ends of creation in Abraham Kuyper and Herman Bavinck' (Skaff, 2015) he sees much good in Kuyper's common grace and doesn't want to dismiss it, but asserts that Kuyper's view of the relationship common and special grace is irreconcilable. He posits that separates special and common grace risks introducing a dualistic understanding of creation, a bifurcation in the work of Christ, and there can be no articulation of an 'evangelical ethics'. He draws on Bavinck and Barth in an attempt to see common grace as being ordered to special grace to avoid some of the issues in Kuyper's approach.

Also on the theme of common grace is van Oorschot's (2015) 'Common grace as a hermeneutical approach to globalization?' Though focusing primarily on the work of Max Stackhouse, the Rimmer and Ruth de Vries Professor of Reformed Theology and Public Life Emeritus, at Princeton Theological Seminary, van Oorschot examines the influence of Kuyper's common grace on his work. This was originally a paper delivered at the Second Amsterdam Kuyper Seminar at the Vrije Universiteit Amsterdam, on the theme of 'Christianity and World Affairs. Building Blocks for International Order Where to Justice and Peace Embrace', in January 2014. She maintains that 'Stackhouse's theological assessment of globalization processes is rooted in his reading of Kuyper's doctrine of common grace' (van Oorschot, 2015:83) and that 'Stackhouse's search for a shared global ethical orientation in a "global ethos" is based on Kuyper's thoughts on the sensus divinitatis and common grace (epistemic dimension)' (van Oorshcot, 2015:86). 
Though like Skaff (2015) - who she doesn't cite - Zuidema (1972), Anderson (2003) and Kaltwasser (2011) she has an issue with common grace and special grace being rooted in Christ as it 'leads to an imbalanced understanding of the common and special soteriological dimension of God's work' (van Oorschot, 2015:91).

Daniel Strange is academic vice-principal and a lecturer in Culture, Religion and Public theology at Oakhill College, London. He is more Van Tillian than Kuyperian but writes out of a respect and admiration for Kuyper in 'Rooted and grounded?' (Strange, 2015). This paper, first delivered at the Evangelical Theological Society Annual Meeting in 2014, draws largely on Kuyper's Rooted and Grounded (Kuyper, 2013a). Strange explores Kuyper's distinction between church as organism and as institute. He begins by placing Kuyper in his context and then sketching his use of the distinction. Strange then poses the important question is the distinction valid? He contends that Kuyper is being 'more speculative and less scriptural in his distinction'. It is 'overly neat and simplistic'. He thinks that the church is a whole and that Kuyper is attempting to separate it. He argues that Kuyper sees the organic nature of the church as having some sort of supremacy; the organic is prioritised over the institute. This, following Zwaanstra (1974), Strange claims is due to his switch from pastor to politician and to the influences of Idealism and Romanticism.

\section{Strange concludes that:}

'I do not think that the institute/organism distinction, as Kuyper understood it, is a safe vehicle in which to carry this agenda forward, for it creates a forced distinction in describing the church, separates the 'organism' from the 'institute', and then stresses the organism to the detriment of the institute, ironically leading to he withering of what the 'organism' is meant to represent and achieve' (Strange, 2015).

He prefers as a distinction the church 'gathered' and the church 'going' or perhaps: "church gathered"' and "church dismissed" (but never dismissed!)'. Though I'm not clear as to how these are better than Kuyper's institute and organism.

While Strange and Skaff debate the finer nuances of 'institute and organism' and 'common grace', Heslam applies these Kuyperian principles to business. In 'The spirit of enterprise: Abraham Kuyper and common grace in business' (Heslam, 2015) he explores the implications of Kuyper's ideas for business. Heslam, whose doctorate was on Kuyper's Stone Lectures (Heslam, 1998), is now focusing on the interface of business, faith and development as a director of Transforming Business, based at Cambridge. In this paper, he draws on Kuyper's common grace to explore this relationship. He notes that Kuyper's common grace ideas are well known, but his ideas on business have been overlooked. This paper is a first attempt to address this issue and to provide an overview of what Kuyper saw as the 'positive potential of business'.

He argues that Kuyper could be seen as a social entrepreneur. Although Kuyper did not address business issues directly he did speak out against sinful activity in finance, consumerism and the desire for wealth above all other concerns. Kuyper also addressed, as Heslam points out, issues of socioeconomic justice. But it was his theme of common grace that provides a basis for 'the positive contribution that business makes to human and social flourishing'.

As Heslam puts it:

'Kuyper's positive view of business includes his ideas about economic freedom and the role of regulation, organized labor and the role of guilds, the eternal value of earthly work, stewardship and philanthropy, economic globalization, business as a "mediating institution" between the individual and the state, the workings of God's grace in business, the social function of money, and the calling of business.'

Heslam then focuses on the latter three. This paper provides an excellent overview of Kuyper's positive view of business. Other articles within this issue of Journal of Markets \& Morality deal with Kuyper's common grace and its application to business (see particularly, Mouw, 2015; Stansbury, 2015; and Baker, 2015).

Three other papers present an overview of Kuyper's work. Kennedy (2015) and Hiemstra (2015) focus on his politics and Beeke (2015) on a broader more introductory view. The latter is a republishing and refreshing of an article that first appeared in Beeke (2004). There is short bibliography that supplements what is largely the text of the 2004 article.

Simon Kennedy, a PhD student at the Centre for the History of European Discourses, University of Queensland, in 'Abraham Kuyper: Calvinist Anti-Revolutionary Politician and Political Thinker' (Kennedy, S. 2015) provides a good overview of Kuyper's life as a politician and his political views. He shows how these were shaped by his Christian faith and more specifically the idea of sphere sovereignty. Although it breaks no new ground Kennedy does provide an accessible introduction to Kuyper's Christian politics and focuses on the VU University and the 'school struggle' and shows how these were practical out workings of his theories. He observes that 'Abraham Kuyper did not articulate a systematic political theory, and his political thought is scattered throughout his various writings and speeches.' Of course, the closest he came to was Ons program, which surprisingly Kennedy doesn't mention. The scattered ideas that Kennedy mentions are structural pluralism and the opposition to state sovereignty, worldview pluralism and the key role sphere sovereignty has to play. He contends that Kuyper's 'understanding of the antithesis between different world views is the foundation of his thought regarding sphere sovereignty and worldview pluralism' and that it is sphere sovereignty that 'forms the basis of Kuyper's political theory'.

Hiemstra (2015), King's University in Alberta, looks at Kuyper's rationale for tolerant public pluralism and shows how neo-Calvinism shaped Kuyper's thought.

Kuyper's sphere sovereignty is examined by North-West University's Mark Rathbone, this time in another political 
context, that of South African apartheid. Rathbone shows that it "was used in an ambiguous if not invidious manner in the history of South Africa, especially during the time of apartheid' (Rathbone, 2015:1). Rathbone's aim in this paper is 'to disentangle Kuyper's concept of sphere sovereignty from these reductions [of race] in order to explore the benefits of an anti-reductionist approach for post-apartheid South Africa' (Rathbone, 2015:2).

Several of the previous papers have been critical of some aspects of Kuyper's thought; the one from Coletto (2015) applies a Kuyperian approach to three key areas of Christian scholarship: science and religion; Trinitarian scholarship; and God's eternity. In each of these three areas he questions the assumptions on which they are based and maintains that 'Kuyper's razor' would help in a surgical assumption-ectomy and shows how the problems can be cut a different way.

\subsection{Online articles and blog posts}

In two articles in the First Things blog (www.firstthings.com), Redeemer University professor David Koyzis looks at several aspects of Kuyper's legacy (Koyzis, 2015a,b). He examines Kuyper's sphere sovereignty in the light of tolerance and idolatry and then applies some of his ideas to evangelism and pluralism.

Bruce Ashford on the Canon and Culture online magazine looks at some of the lessons from Kuyper that will enable us to be more distinctive in how we act and interact in politics and in the public square (Ashford, 2015a). These include discerning God's creation design, promoting 'principled pluralism' and avoid a coercive relationship between church and state. This post is essentially a conflation of two chapters from his excellent book Every Square Inch (Ashford, 2015b). As Ashford puts it here:

'Kuyper grasped one great truth - that Christ's lordship is universal - and sought to apply it wisely and consistently to life on this earth. And from that we can all benefit.'

Mike Wagenman, who recently obtained his doctorate from Bristol University on Kuyper's approach to power and the church (Wagenman, 2014), has a helpful piece at the 'Do Justice' blog. He draws on Kuyper to examine the question what role should the church play in social issues. He takes issue with the 'Let the church preach the Gospel and let Christians engage in the public square!' approach which is often justified by an appeal to Kuyper's church as institute and organism. According to Wagenman:

'Kuyper demanded that the institutional church's proclamation of the Gospel be world-wide, concerned with all of Creation. The institutional church's field of interest must be as wide as God's redemptive interest, which is "all things," wider than what we typically understand to be "ecclesial," "religious," or "spiritual." The light of the Gospel must address and illumine every part of Creation' (Wagenaman, 2015).
To fail to address these issues - which doesn't mean the church should demand certain political policies - is for the church to fail to be 'the incarnational presence of Jesus in the world' and fails to be the ambassador of Christ.

\section{REVIEWS}

\subsection{Bratt's Abraham Kuyper}

One of the major works on Kuyper to appear in recent years was James Bratt's biography: Abraham Kuyper (Bratt, 2013). In 2015 we saw several reviews of this book (Brock, 2015; Kaemingk, 2015; Kennedy, J., 2015; Lofton 2015; Wood, 2015). ${ }^{5}$

All reviews affirm the importance of Bratt's work. Lofton, despite her disliking Kuyper, describes the biography as 'relentlessly comprehensive' (Lofton, 2015:462); Brock rightly observes that 'Bratt is a fair, balanced, and careful historian who makes much of Kuyper's profound contextual insight, unique application of Calvinist theology, and lasting theological and political legacy without hiding Kuyper's tendency towards sweeping generalization, blind hubris, and glaring defects.' Wood even thinks that it will be a 'standard for studies in modern and social religious history' (Wood, 2015:454). Though James Kennedy - recently appointed the Dean of University College Utrecht - does recognise some of the biography's limits: 'To Kuyper specialists, Bratt's biography may not yield radically new insights' but on the positive side he notes that 'Bratt rescues Kuyper from a narrow Netherlandic focus and allows for new reflection about the historical significance of this outsized and controversial figure' (Kennedy, J., 2015).

\subsection{Other reviews}

Two of Kuyper's translations from 2013 and 2011 were reviewed. Covolo (2015) looked at Scholarship (Kuyper, 2013) and Felch (2015) provided an extended review of Wisdom and Wonder (Kuyper, 2011) and used that to analyse Kuyper's perspective on science. Felch concludes that Kuyper's Wisdom and Wonder 'asserts that the work of science is ultimately God's work'; and 'reminds us of the significance of worldview assumptions in discussions related to science'.

The same issue of Themelios that contained Covolo's review also had a review by Wozinicki (2015) on Kuyper Centre Review 4.

James Kennedy (2015) had an online review of Wood's Going Dutch (Wood 2013). He is justly positive about Wood's work: 'Anyone who wants to understand Kuyper's central preoccupation - his ecclesiology, institutional and organic should read Wood's book, which is meticulously researched and carefully reasoned.'

\section{THESES}

Himes (2015) successfully defended a PhD at Fuller supervised and examined by Richard Mouw and A.L. de Bruijne. 'For a better worldliness: The theological discipleship of Abraham

$5 \quad$ See also the review in Bishop (2013) 
Kuyper and Dietrich Bonhoeffer' examines the question 'what does it mean to follow after Jesus?' To do this Himes looks at the notion of Christian discipleship in Bonhoeffer and Kuyper. The section on Kuyper focuses on the development and practice of discipleship in Kuyper from 1894-1905 and looks at how it shaped his public actions. The final section compares Kuyper and Bonhoeffer's theology and practices of discipleship.

\section{CONCLUSION}

This survey of pieces published in 2015 shows that the interest in Kuyper is not waning. Kuyper's common grace, sphere sovereignty, and the notion of church as institute and organism, in particular, are still - despite some suggestions for modification - are still fruitful approaches to what has been termed 'public theology'. The promised new translations of Kuyper's Pro Rege and other works, will also do much to ensure his legacy will continue.

\section{REFERENCES}

\section{Works reviewed}

Ashford, B. 2015. Lessons from father Abraham (Kuyper): Christianity, politics, \& the public square. Canon and Culture (6 March) online: http://www. canonandculture.com/lessons-from-father-abraham-kuyper-christianity-politics-the-public-square/

Beeke, J.R. 2015. The life and vision of Abraham Kuyper' (In Baines, R.S., Barcellos R.C. \& Butler, J.P. (eds), Common Confession: Essays in Honor of James M. Renihan, Palmdale, CA, Reformed Baptist Academic Press, p. 175-194). ISBN 978-0991659937

Brock, C. 2015. 'Review of Abraham Kuyper by Bratt, J. Journal of Theological Studies, 66 (1):496-499. doi: 10.1093/jts/flu202

Coletto, R. 2015. Kuyper's razor? Rethinking science and religion, trinitarian scholarship and God's eternity. In die Skriflig, 49(1), Art. \#1891, 10 pages. http:// dx.doi.org/10.4102/ids. v49i1.1891

Felch, D.A. 2015. Science as God's work: Abraham Kuyper's perspective on science: A review article. Ordained Servant (January) Online http://www.opc.org/ os.html?article_id=463\&issue_id=101

Friesen, J.G. 2015. Neo-Calvinism and Christian Theosophy: Franz Baader, Abraham Kuyper, Herman Dooyeweerd. Calgary: Aevum Books. ISBN 9780994775108.

Graham, G. (ed.) 2015. Church and Academy. The Kuyper Center Review 5. Grand Rapids: Eerdmans. xii +142 pages. ISBN 978-0-8028-7245-6

Heslam, P.S. 2015. The spirit of enterprise: Abraham Kuyper and common grace in business. Journal of Markets \& Morality, 18(1), 7-20.

Himes, B.M. 2015. For a better worldliness: The theological discipleship of Abraham Kuyper and Dietrich Bonhoeffer. PhD Thesis Fuller Theological Seminary, Center for Advanced Theological Study.

Kaemingk, M. 2015. Bold, beautiful and broken [Review of Abraham Kuyper by Bratt, J.,] Books \& Culture 21(4) (July/ August):8-10.

Kennedy, J. 2015. Review of Abraham Kuyper by Bratt, J. Low Countries Historical Review, 130(3). DOI: http://doi.org/10.18352/bmgn-lchr.10108

Koyzis, D. 2015. What would Kuyper do?_Idolatry and the limits of pluralism, First Things 23 January. Online: http://www.firstthings.com/blogs/firstthoughts/2015/01/principled-pluralism-and-idolatry

Koyzis, D. 2015. When we turn inward: evangelism and the limits of pluralism (part 2). First Things 4 February. Online: http://www.firstthings.com/web-exclusives/2015/02/when-we-turn-inward

Kuyper, A. 2015a. Our program: A Christian political manifesto. Bellingham, WA.: Lexham Press. xviii +410 pages, ISBN: 978-1577996552

Kuyper, A. 2015b. God's angels: His ministering spirits. (Translated by Richard Stienstra), Vancouver, BC, Friesen Press. viii + 360 pages ISBN 978-1-46026908-4

Kuyper, A. 2015c. 'The natural knowledge of God'. (Translated by Harry van Dyke). Online:http://www.allofliferedeemed.co.uk/Van\%20Dyke/AKNaturalKnowledgeOfGod.pdf

Kuyper, A. 2015d. The worship of the Reformed Church and the creation of its service book. Translated by James A. De Jong. Calvin Theological Journal 50(1):59-90.

Larson, M.J. 2015. Abraham Kuyper, conservatism, and the church and state. Eugene, OR: Wipf \& Stock. xii + 111 pages. ISBN 978-1-49821956-3. 
Lofton, K. 2015. 'Review of Abraham Kuyper by Bratt, J. Church History, 84(2):462-465.

Nijhof, R. 2015. Review of Neo-Calvinism and Christian Theosophy by Friesen, J.G. Philosophia Reformata, 80:236-240.

Rathbone, M., 2015, 'Sphere sovereignty and irreducibility: The ambiguous use of Abraham Kuyper's ideas during the time of apartheid in South Africa. Koers - Bulletin for Christian Scholarship 80(1), Art. \#2208, 8 pages.

Skaff, J. 2015. Common grace and the ends of creation in Abraham Kuyper and Herman Bavinck. Journal of Reformed Theology, 9(1): 3-18.

van Oorschot, F. 2015. Common grace as a hermeneutical approach to globalization? Philosophia Reformata, 80:78-98.

Wagenman, M, 2015, 'What Kuyper really said about the church and politics', online: http://dojustice.crcna.org/article/what-kuyper-really-said-aboutchurch-and-politics

Wood, J.H. Jr. 2015. Review of Abraham Kuyper by Bratt, J. Journal of Ecclesiastical History, 66(2), 454. http://dx.doi.org/10.1017/S0022046914002206

\section{Other works mentioned}

Anderson, C.B. 2003. A canopy of grace: Common and particular grace in Abraham Kuyper's theology of science. Princeton Seminary Bulletin 24(1):122-140.

Baker, B. 2015. Entrepreneurship as a sign of common grace. Journal of Markets \& Morality, 18(1):81-98.

Beeke, J. 2004. The life and vision of Abraham Kuyper. Church \& Society, 14(1):2431

Bratt, J.D. 2013. Abraham Kuyper: Modern Calvinist Christian Democrat, Grand Rapids, MI.: Eerdmans. xxviii + 455 pages. ISBN 978-0-8028-6906-7.

Dooyeweerd, H. 2013. Kuyper's philosophy of science. (In S. Bishop \& J. Kok On Kuyper. Sioux Center: Dordt College Press. p. 153-178).

Friesen, J.G. 2003. The mystical Dooyeweerd once again: Kuyper's use of Franz von Baader. Ars Disputandi, 3(1):344-348. Online: http://www.tandfonline. com/doi/abs/10.1080/15665399.2003.10819803

Heslam, P.S. 1998. Creating a Christian worldview: Abraham Kuyper's Lectures on Calvinsim. Carlisle: Paternoster.

Kaltwasser, C.J. 2011. Assessing the Christological foundation of Kuyper's doctrine of common grace. (In Bowlin, J. (ed.) Revelation and Common Grace, The Kuyper Center Review 2, Grand Rapids: Eerdmans. p. 200-220).

Kuipers, T. 2011. Abraham Kuyper: An annotated bibliography 1857-2010. Leiden: Brill. xxvii + 756 pages. ISBN 978-90-04-21139-1

Kuyper, Abraham. 2011. Wisdom and wonder. Grand Rapids, MI. Christian's Library Press. 191 pages. ISBN 978-1-937498-90-0

Kuyper, A. (Harinck, G. ed.) 2012. Kuyper in America: This is where I was meant to be. Sioux Center, IA. Dordt College Press. $x+84$ pages. ISBN 978-0932914934.

Kuyper, A. 2013a. Rooted and grounded: The church as organism and institution. Grand Rapids: Christian's Library Press. xxv + 45 pages. ISBN 978-1-93894853-4.

Kuyper, A. 2013b. Guidance for Christian engagement in government (translated by Harry van Dyke). Grand Rapids, MI.: Christian's Library Press. 384 pages. ISBN 978-1-938948-61-9.

Kuyper, A. 2013c, Common grace: Volume 1: The historical section. Part 1: Noah-Adam, translated by Nelson D. Kloosterman \& Ed M. van der Maas, edited by Jordan J. Ballor \& Stephen J. Grabill. Grand Rapids: Christian's Library Press.
Kuyper, A. 2013b. Guidance for Christian engagement in government. Translated and edited by Harry van Dyke. Grand Rapids: Christian's Library Press.

Kuyper, A. 2014. Scholarship: Two convocation addresses on university life. Translated by Harry van Dyke. Grand Rapids: Christian's Library Press.

Mouw, R. 2015. Getting the trophies ready: Serving God in the business world. Journal of Markets \& Morality, 18(1):189-198.

Stansbury, J. 2015. Moral imagination as a reformational influence in the workplace. Journal of Markets \& Morality, 18(1):21-41.

Van Til, H. 1972. The Calvinistic Concept of Culture. Philadelphia: Presbyterian \& Reformed.

Wagenman, M. 2014. A critical analysis of the power of the church in the ecclesiology of Abraham Kuyper. PhD Thesis, Bristol University and Trinity College.

Wood, J.H. Jr. 2013. Going Dutch in the modern age: Abraham Kuyper's struggle for a free church in the Netherlands. Oxford: Oxford University Press. $x+235$ pages. ISBN 978-0-19-992038-9.

Zuidema, Syste U. 1972. Common Grace and Christian Action in Abraham Kuyper. (In Zuidema, S.U. (ed.) Communication and confrontation. A philosophical appraisal and critique of modern society and contemporary Thought. Kampen Kok. p. 52-105).

Zwaanstra, H. 1974. Abraham Kuyper's conception of the church. Calvin Theological Journal, 9, 149-81. 
